\title{
Effects of 8-Week Core Exercises on Free Style Swimming Performance of Female Swimmers Aged 9-12
}

\author{
Yıldırım Gökhan GENCER ${ }^{1}$ \\ 'Tuzuncu Til University, School of Physical Education and Sports, Van/Turkey \\ Email:ygokhangencer@hotmail.com
}

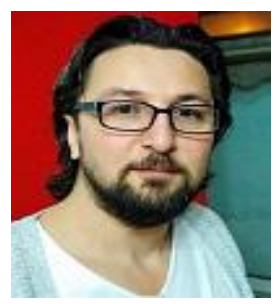

\begin{abstract}
With this study, it is aimed to review the effects of 8-week core exercises, which are scheduled before the routine exercises, on changes over certain physical and motoric attributes and freestyle swimming performance of female athletes of the youngest age group, which is 9-12. For the study, a group of 12 female licensed swimmers who had a swimming background of 3 years in city of Van is chosen to be core exercise group (CEG) and set as experimental group. And 12 female swimmers are chosen to be in control group. The athletes are scheduled to perform regular swimming exercises for competition, five days a week and for approximately 90 minutes per day. In addition to control group, CEG is scheduled to perform 20 minutes of low intensity, fixed duration and repetitive core exercises before every routine exercise for 8 weeks. Chosen measurements are obtained from the athletes both at the beginning and after 8 weeks and the change between pretest and posttest values is evaluated. For the statistical data analysis, nonparametric tests of Wilcoxon and Mann Whitney U tests are used. As a results of the study, the group of swimmers aged 9-12 who underwent 8 weeks of low intensity core exercises showed differences compared to pretest and posttest values of control group, even though not statistically significant $(p>0,05)$. As a result, compared to the control group, a 1-2 seconds of decrease especially when it is a very important amount for this sport - in $25 \mathrm{~m}$ and $50 \mathrm{~m}$ free style swimming ranks is attributed to the effect of core exercises, and it is reckoned that low intensity core exercises may positively affect the free style swimming performance of female swimmers aged 9-12.
\end{abstract}

Keywords: Freestyle, Swimming, Core training.

Citation | Ylldırım Gökhan GENCER (2018). Effects of 8-Week Core Exercises on Free Style Swimming Performance of Female Swimmers Aged 9-12. Asian Journal of Education and Training. 4.(3): $182-185$.

History:

Received: 3 April 2018

Revised: 23 April 2018

Accepted: 25 April 2018

Published: 26 April 2018

Licensed: This work is licensed under a Creative Commons

Attribution 3.0 License (c) Er

Publisher: Asian Online Journal Publishing Group
Funding: This study received no specific financial support

Competing Interests: The author declares that there are no conflicts of interests regarding the publication of this paper.

Transparency: The authors confirm that the manuscript is an honest, accurate, and transparent account of the study was reported, that no vital accurate, and transparent account of the study was reported; that no vital study as planned have been explained.

study as planned have been explained.
Ethical: This study follows all ethical practices during writing.

\section{Contents}

1. Introduction

References... 


\section{Introduction}

Swimming, which has ever-increasing popularity, is a sports branch of high demand in Olympic games and international championships. Swimming enables symmetrical and balanced development of human muscles and it ensures that $80 \%$ of the muscle mass is being used when in water. For this reason, it could be said that an athlete swimming a certain distance burns the energy of 4 times more than that of the athlete who runs it. When it is performed as a sport, swimming contributes to the improvement of attributes such as skill, coordination, power, stamina, speed, velocity and mobility. Additionally, it is among the sport activities which provide a sense of discipline and confidence (Bozdogan, 1986; Odabaş, 2003). There are four branches of swimming: crawl stroke, butterfly stroke, back stroke and breast stroke. Crawl, in other words free style swimming, is the fastest form of swimming among other competition styles (Hannula and Thornton, 2001; Yapicl et al., 2016).

Certain anthropometric attributes may affect performance of swimmers. Successful swimmers are generally tall and have long extremities and wide shoulders. And also mid and upper parts of their body hold a large muscle mass. When the factors effecting the performance are reviewed, it is seen that the power of muscles is a major contributing factor (Troup, 1999). In swimming, there are certain studies in which the athlete uses certain materials in water (such as pedals, pallets, pull-buoys and stamina rubber) to help increase the velocity and also to keep it. Power exercises in swimming are divided into two groups: the ones performed in the water and the ones performed on the ground. Power studies performed on the ground include weight exercises, medicine ball exercises, leaping exercises, exercises for the core area, exercises of body weight, vasa trainer or isokinetic swim bench studies in which isokinetic movements are done, thera band and rubber exercises, trx exercises, foam-roll usage and many others which are used during any period (Yapicı et al., 2016). Core exercises have gained a great deal of popularity recently and have an important place in exercise plans (Riewald, 2003).

The physiological effects of exercises on athletes have been subject matter for many studies (Sarikaya et al., 2016). Day by day, when the compatibility of physical attributes of athletes for the performed branch of sports is evaluated among the small or young athlete category who has taken up the sports rather recently, anthropometric and bio-motoric attributes of athletes of that age and their effect on the athlete's performance have captured the attention of researchers. With this study, it is aimed to review the effects of 8-week core exercises, which are scheduled before the routine exercises, on changes over certain physical and motoric attributes and freestyle swimming performance of female athletes of the youngest age group, which is 9-12.

\section{Method}

For the study, a group of 12 female licensed swimmers who had a swimming background of 3 years in city of Van is chosen to be core exercise group (CEG) and set as experimental group. And 12 female swimmers are chosen to be in control group. The athletes are scheduled to perform regular swimming exercises for competition, five days a week and for approximately 90 minutes per day. In addition to control group, CEG is scheduled to perform 20 minutes of low intensity, fixed duration and repetitive core exercises before every routine exercise for 8 weeks. After core exercises, the athletes are given 10 minutes of breaks and then moved on to swimming exercises. With both groups, repetition method is used for rapid swimming of short distances in water exercises and in order to avoid accumulated lactic acid, break periods between work outs are paid attention to. Chosen measurements are obtained from the athletes both at the beginning and after 8 weeks and the change between pretest and posttest values is evaluated.

Core Exercise Program: The below stated actions are applied in low intensity and one set for every motion with 1 minute of intervals in between every different motion.

Bridge: 5 minutes of static standing in bridge position and then lowering is performed for 10 times.

Body Extension: Athlete sits on the ground with bent knees and lifts the arms towards the front and moves them towards the back with 45-degree angle. After 10 seconds of waiting at this position, athlete changes the position to the beginning. This is repeated for 10 times.

Sit-ups: After raising the head and shoulders up for 10 times, 5 seconds of static standing is followed by the position change to the beginning.

Sit-ups on Roman Chair: Athlete performs a static standing for 5 seconds on roman chair with bent knees and with hands cross positioned on the chest in sit up position and then changes position to the beginning, with 10 repetitions.

Abdominal Contraction: Athlete is requested to contract and loosen abdominal muscles for 5 seconds with knees bent and hands cross positioned on the chest while breathing in and out. This is repeated for 10 times.

Lower extremity ground rotation: In lying back position, arms are spread to the sides and body stabilization is ensured with bending the knees at 90 degrees. Then, the athlete is requested to do a rotation to right and left. This rotation is repeated for 10 times, to be 5 seconds on the left and 5 seconds on the right.

Leg Scissors Movement: In lying back position, legs are stretched and the heels are raised by $10 \mathrm{~cm}$ off of the ground and then lowered. The athlete is asked to repeat this movement for 10 times for each leg (Kahle and Tevald, 2014; Yuksel et al., 2016).

Height measurements of participants are taken with measurement machine of brand Detecto, with $0,1 \mathrm{~cm}$ sensitivity. Weight measurements are taken with measurement machine of brand Detecto with 100 grams of sensitivity. Height and weight measurements are used to calculate body mass indices. Right and left grip force measurements are taken by using Takei brand hand dynamometer. For vertical jumps, Takei brand vertical jump meter, for horizontal jumps standard meters with $0,1 \mathrm{~cm}$ sensitivity, for $30 \mathrm{~m}$ running test Sinar Photocell Telemetric Stop Watch are used. Durations of 10 push-ups that are performed in fastest possible way and also in a regular way are recorded in seconds. Additionally, the best of 2 trials of $25 \mathrm{~m}$ and $50 \mathrm{~m}$ free style swimming ranks are recorded by using Colorado Time Systems-SSF device in seconds and split seconds with scoreboard. For the statistical data analysis, non-parametric tests of Wilcoxon and Mann Whitney U tests are used. 


\section{Findings}

Mean age for experimental group is $10,58 \pm 1,31$, and for control group it is $10,75 \pm 1,29$.

Table-1. Control and CEG group pretest and posttest comparison

\begin{tabular}{|c|c|c|c|c|c|c|c|c|}
\hline \multirow{2}{*}{ Variables } & \multirow{2}{*}{$\mathbf{N}$} & \multirow{2}{*}{ Tests } & \multicolumn{3}{|l|}{ Control Group } & \multicolumn{3}{|l|}{ CAG } \\
\hline & & & $\mathbf{X} \pm \mathbf{S s}$ & $\mathbf{Z}$ & $\mathbf{P}$ & $\mathrm{X} \pm \mathrm{Ss}$ & $\mathbf{Z}$ & $\mathbf{P}$ \\
\hline \multirow{2}{*}{ Weight (kg) } & \multirow[t]{2}{*}{12} & Pre-Test & $38,58 \pm 5,17$ & \multirow[t]{2}{*}{$-1,604^{a}$} & \multirow[t]{2}{*}{, 109} & $36,37 \pm 7,65$ & \multirow[t]{2}{*}{$-2,278^{\mathrm{a}}$} & \multirow[t]{2}{*}{,023* } \\
\hline & & Post-Test & $38,86 \pm 5,29$ & & & $37,31 \pm 8,01$ & & \\
\hline \multirow{2}{*}{ Height $(\mathrm{cm})$} & \multirow[t]{2}{*}{12} & Pre-Test & $145,08 \pm 12,17$ & \multirow[t]{2}{*}{$-2,588^{\mathrm{a}}$} & \multirow[t]{2}{*}{,010** } & $140,92 \pm 13,76$ & \multirow[t]{2}{*}{$-3,081^{a}$} & \multirow[t]{2}{*}{,002** } \\
\hline & & Post-Test & $146,08 \pm 12,24$ & & & $143,67 \pm 12,94$ & & \\
\hline \multirow{2}{*}{ BMI } & \multirow[t]{2}{*}{12} & Pre-Test & $18,34 \pm 1,35$ & \multirow[t]{2}{*}{$-1,362^{\mathrm{b}}$} & \multirow[t]{2}{*}{, 173 } & $18,19 \pm 1,83$ & \multirow[t]{2}{*}{,$- 941^{\mathrm{b}}$} & \multirow[t]{2}{*}{,347 } \\
\hline & & Post-Test & $18,21 \pm 1,25$ & & & $17,93 \pm 1,88$ & & \\
\hline \multirow{2}{*}{ Horizontal Jump (cm) } & \multirow[t]{2}{*}{12} & Pre-Test & $130,83 \pm 14,87$ & \multirow[t]{2}{*}{$-3,069^{\mathrm{a}}$} & \multirow[t]{2}{*}{,002** } & $140,50 \pm 24,63$ & \multirow[t]{2}{*}{$-3,065^{\mathrm{a}}$} & \multirow[t]{2}{*}{,002*** } \\
\hline & & Post-Test & $134,92 \pm 14,74$ & & & $146,92 \pm 23,24$ & & \\
\hline \multirow{2}{*}{$30 \mathrm{~m}(\mathrm{sec})$} & \multirow[t]{2}{*}{12} & Pre-Test & $6,08 \pm, 47$ & \multirow[t]{2}{*}{$-1,142^{\mathrm{a}}$} & ,253 & $5,97 \pm, 40$ & $-2,199^{b}$ & ,028* \\
\hline & & Post-Test & $6,10 \pm, 47$ & & & $5,80 \pm, 47$ & & \\
\hline & 12 & Pre-Test & $10,25 \pm 1,54$ &,$- 944^{\mathrm{a}}$ & ,345 & $10,44 \pm 1,58$ & $-2,040^{b}$ &, $041^{*}$ \\
\hline Push-up (sec) & & Post-Test & $10,24 \pm 1,57$ & & & $9,59 \pm 1,40$ & & \\
\hline & 12 & Pre-Test & $41 \pm 5,80$ & $-2,831^{a}$ & ,005*** & $41 \pm 4,55$ & $-2,958^{\mathrm{a}}$ & ,003** \\
\hline Vertical Jump (cm) & & Post-Test & $42,91 \pm 5,76$ & & & $43,25 \pm 4,82$ & & \\
\hline Anaerobic & 12 & Pre-Test & $547,62 \pm 97,47$ & $-2,934^{a}$ & ,003** & $516,88 \pm 119,69$ & $-2,981^{\mathrm{a}}$ & ,003*** \\
\hline$(\mathrm{kg} / \mathrm{sec})$ & & Post-Test & $564,32 \pm 99,07$ & & & $544,71 \pm 127,68$ & & \\
\hline$H^{\prime}$ & 12 & Pre-Test & $18,88 \pm 3,47$ & $-3,061^{a}$ &, $002^{* *}$ & $19,05 \pm 4,66$ & $-3,061^{\mathrm{a}}$ & ,002** \\
\hline Hand Grip Force Kight & & Post-Test & $20,23 \pm 3,85$ & & & $21,40 \pm 4,95$ & & \\
\hline & 12 & Pre-Test & $16,75 \pm 3,31$ & $-3,064^{a}$ & ,002** & $18,92 \pm 6,63$ & $-3,062^{\mathrm{a}}$ & ,002*** \\
\hline Hand Grip Force Left & & Post-Test & $17,45 \pm 3,12$ & & & $20,91 \pm 7,46$ & & \\
\hline & 12 & Pre-Test & $20,13 \pm 2,21$ & $-554^{\mathrm{b}}$ &, 580 & $20,21 \pm 2,40$ & $-3,059^{b}$ &, $002^{* *}$ \\
\hline $25 \mathrm{~m}$ Free Style (sec) & & Post-Test & $20,03 \pm 2,10$ & & & $18,85 \pm 1,90$ & & \\
\hline 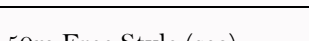 & 12 & Pre-Test & $42,19 \pm 4,42$ & $-2,353^{\mathrm{b}}$ & ,019* & $42,33 \pm 4,28$ & $-3,059^{b}$ & ,002** \\
\hline $50 \mathrm{~m}$ F ree style (sec) & & Post-Test & $41,77 \pm 4,16$ & & & $40,25 \pm 3,93$ & & \\
\hline
\end{tabular}

As can be seen in Table 1, in the pretest and posttest comparisons, in all parameters, significant differences are seen $(* \mathrm{p}<0,05, * * \mathrm{p}<0,01)$ except for height, vertical and horizontal jumps, hand grip right and left, anaerobic power and $50 \mathrm{~m}$ free style swimming parameters for control group and except for Body Mass Index (BMI) for CEG.

Table-2. Comparison of Control and CEG groups pretest and posttest results

\begin{tabular}{|c|c|c|c|c|c|c|}
\hline Variables & $\mathbf{N}$ & Tests & $\begin{array}{l}\text { CEG } \\
\mathrm{X} \pm \mathrm{Ss} \\
\end{array}$ & $\begin{array}{l}\text { Control Group } \\
\mathrm{X} \pm \mathrm{Ss}\end{array}$ & $\mathbf{Z}$ & $\mathbf{P}$ \\
\hline Age (year) & 12 & Pre-Test & $10,75 \pm 1,29$ & $10,58 \pm 1,31$ &,- 363 &, 717 \\
\hline \multirow{2}{*}{ Weight (kg) } & \multirow[t]{2}{*}{12} & Pre-Test & $36,37 \pm 7,65$ & $38,58 \pm 5,17$ &,- 808 & 4419 \\
\hline & & Post-Test & $37,31 \pm 8,01$ & $38,86 \pm 5,29$ &,- 462 & ,644 \\
\hline \multirow[b]{2}{*}{ Height (cm) } & \multirow[t]{2}{*}{12} & Pre-Test & $140,92 \pm 13,76$ & $145,08 \pm 12,17$ &,- 752 &, 452 \\
\hline & & Post-Test & $143,67 \pm 12,94$ & $146,08 \pm 12,24$ &,- 347 & ,728 \\
\hline \multirow{2}{*}{ BMI } & \multirow[t]{2}{*}{12} & Pre-Test & $18,19 \pm 1,83$ & $18,34 \pm 1,35$ &,- 231 &, 817 \\
\hline & & Post-Test & $17,93 \pm 1,88$ & $18,21 \pm 1,25$ &,- 346 & ,729 \\
\hline \multirow{2}{*}{ Horizontal Jump (cm) } & \multirow[t]{2}{*}{12} & Pre-Test & $140,50 \pm 24,63$ & $130,83 \pm 14,87$ &,- 983 & ,326 \\
\hline & & Post-Test & $146,92 \pm 23,24$ & $134,92 \pm 14,74$ & $-1,416$ & , 157 \\
\hline \multirow[b]{2}{*}{$30 \mathrm{~m}(\mathrm{sec})$} & \multirow[t]{2}{*}{12} & Pre-Test & $5,97 \pm, 40$ & $6,08 \pm, 47$ &,- 635 &, 525 \\
\hline & & Post-Test & $5,80 \pm, 47$ & $6,10 \pm, 47$ & $-1,704$ & ,088 \\
\hline \multirow{2}{*}{ Push-up (sec) } & \multirow[t]{2}{*}{12} & Pre-Test & $10,44 \pm 1,58$ & $10,25 \pm 1,54$ &,- 202 &, 840 \\
\hline & & Post-Test & $9,59 \pm 1,40$ & $10,24 \pm 1,57$ & $-1,155$ & ,248 \\
\hline \multirow{2}{*}{ Vertical Jump (cm) } & \multirow[t]{2}{*}{12} & Pre-Test & $41 \pm 4,55$ & $41 \pm 5,80$ &,- 174 & ,862 \\
\hline & & Post-Test & $43,25 \pm 4,82$ & $42,91 \pm 5,76$ &,- 289 & ,772 \\
\hline \multirow{2}{*}{ Anaerobic Power (kg/sec) } & \multirow[t]{2}{*}{12} & Pre-Test & $516,88 \pm 119,69$ & $547,62 \pm 97,47$ &,- 866 & ,386 \\
\hline & & Post-Test & $544,71 \pm 127,68$ & $564,32 \pm 99,07$ &,- 404 & ,686 \\
\hline \multirow[b]{2}{*}{ Hand Grip Force Right } & \multirow[t]{2}{*}{12} & Pre-Test & $19,05 \pm 4,66$ & $18,88 \pm 3,47$ &,- 058 & ,954 \\
\hline & & Post-Test & $21,40 \pm 4,95$ & $20,23 \pm 3,85$ &,- 433 & ,665 \\
\hline \multirow{2}{*}{ Hand Grip Force Left } & \multirow[t]{2}{*}{12} & Pre-Test & $18,92 \pm 6,63$ & $16,75 \pm 3,31$ &,- 809 & 419 \\
\hline & & Post-Test & $20,91 \pm 7,46$ & $17,45 \pm 3,12$ & $-1,328$ & , 184 \\
\hline \multirow[b]{2}{*}{ 25m Free Style (sec) } & \multirow[t]{2}{*}{12} & Pre-Test & $20,21 \pm 2,40$ & $20,13 \pm 2,21$ & ,OO & 1,000 \\
\hline & & Post-Test & $18,85 \pm 1,90$ & $20,03 \pm 2,10$ & $-1,501$ & ,133 \\
\hline \multirow[b]{2}{*}{ 50m Free Style (sec) } & \multirow[t]{2}{*}{12} & Pre-Test & $42,33 \pm 4,28$ & $42,19 \pm 4,42$ &,- 115 & ,908 \\
\hline & & Post-Test & $40,25 \pm 3,93$ & $41,77 \pm 4,16$ &,- 866 & ,386 \\
\hline
\end{tabular}

As can be seen in Table 2, no statistically significant difference is seen in the comparison of pretest and posttest of CEG and control group. 


\section{Conclusion}

As a results of the study, the group of swimmers aged 9-12 who underwent 8 weeks of low intensity core exercises showed differences compared to pretest and posttest values of control group, even though not statistically significant. Due to the fact that in the control group there are no statistically significant differences between the pretest and posttest values of parameters such as weight, 10 sec push up, $30 \mathrm{~m}$ running and $25 \mathrm{~m}$ free style swimming, it is reckoned that control group developed less than the CEG in terms of 10 sec push up, $30 \mathrm{~m}$ running and $25 \mathrm{~m}$ free style swimming. When literature is reviewed, core exercises especially play an important role in the development of motor skills (Samson, 2005; Samson et al., 2007; Ping et al., 2011; Saeterbakken et al., 2011; Atıcl, 2013; Afyon, 2014; Afyon and Boyacı, 2016; Rostami and Ghaedi, 2017). However, contradictory results are also seen on their effect on the performance (Cissik, 2011; Patil et al., 2014). In alignment with the performed study, Gönener et al. (2017) found out that core exercises have effects on $100 \mathrm{~m}$ swimming performance of male swimmers aged 13-15, with back stroke style and they emphasize that core exercises should be used in groundwork exercises. Patil et al. (2014) state that, as a result of the study they carried out with 60 young swimmers with a mean age of $14,2 \pm 1,49,6$ weeks of core exercises have effect on $50 \mathrm{~m}$ free style swimming $(\mathrm{p}<0,05)$. In the literature, effects of core exercises on performance are a topic which has been scarcely studied on (Hibbs et al., 2008; Martens et al., 2011; Patil et al., 2014). However, for other branches there are various studies carried out. Yuksel et al. (2016) put forward their effect on hit rates of basketball players and state that this is due to the effect of core exercises on the balance parameter. Michael et al. (2005) checked the effects of core exercises on rowers and in alignment with this study, report that there is significant change in vertical jump parameter. Bilici and Selçuk (2018), as a result of their study performed with female volleyball players aged 14-16, state that 10 weeks of core exercises strengthen jumps and also the central area. Aslan (2014) puts forward that there is significant change in non-dominant leg force however core exercises do not affect dominant leg force. Even though in CEG's pretest and posttest comparison, the fact that there was no significant change makes one think that additional core exercises do not statistically affect the development of athletes, it is seen that in-group development of CEG is higher than that of control group both in terms of value and in terms of parameter. As a result, compared to the control group, a 1-2 seconds of decrease - especially when it is a very important amount for this sport - in $25 \mathrm{~m}$ and $50 \mathrm{~m}$ free style swimming ranks is attributed to the effect of core exercises, and it is reckoned that low intensity core exercises may positively affect the free style swimming performance of female swimmers aged 9-12.

\section{References}

Afyon, Y.A., 2014. Effect of core training on 16 year-old soccer players. Educational Research and Reviews, 9(23): 1275. View at Google Scholar

Afyon, Y.A. and A. Boyac1, 2016. The effects of 8-week core training on the development of some motoric features among 18 year-old footballers. Journal of Human Sciences, 13(3): 4595-4603. View at Google Scholar $\mid$ View at Publisher

Aslan, A.K., 2014. Effects of an 8-weeks core training on balance and functional performance in young soccer players. Doctoral Thesis, Selcuk University Health Sciences Institute. Konya/Turkey.

Atıcı, M., 2013. Investigating the effect of core training on some physiological and motoric parameters in women aged 18-24 who are swimming. Muğla Sıtkı Koçman University, Institute of Health Sciences, Department of Physical Education and Sport, Department of Physical Education and Sports Teacher Education, Master Thesis, Mugla/Turkey

Bilici, Ö.F. and M. Selçuk, 2018. Evaluation of the effect of core training on the leap power and motor characteristics of the 14-16 years old female volleyball players. Journal of Education and Training Studies, 6(4): 90-97. View at Google Scholar $\mid$ View at Publisher

Bozdogan, A., 1986. Swimming technical analysis and methodology. Istanbul: Visual Arts Printing.

Cissik, J.M., 2011. The role of core training in athletic performance, injury prevention, and injury treatment. Strength \& Conditioning Journal, 33(1): 10-15.

View at Google Scholar $\mid$ View at Publisher
Gönener, A., U. Gönener, O. Yllmaz, T. Horoz and D. Demirci, 2017. The effect of 8 -week thera-band exercises on male swimmers $100 \mathrm{~m}$ freestyle swimming performance. Journal of Human Sciences, 14(4): 3950-3955. View at Google Scholar $\mid$ View at Publisher

Hannula, D. and N. Thornton, 2001. The swim coaching bible. America: Human Kinetics, 1:21

Hibbs, A.E., K.G. Thompson, D. French, A. Wrigley and I. Spears, 2008. Optimizing performance by improving core stability and core strength. Sports Medicine, 38(12): 995-1008. View at Google Scholar $\mid$ View at Publisher

Kahle, N. and M.A. Tevald, 2014. Core muscle strengthening's improvement of balance performance in community-dwelling older adults: A pilot study. Journal of Aging and Physical Activity, 22(1): 65-73. View at Google Scholar $\mid$ View at Publisher

Martens, J., I.P. Einarsson, N. Schnizer, F. Staes and D. Daly, 2011. Lower trunk muscle activity during front crawl swimming in a single leg amputee. Portuguese Journal of Sports Sciences, 11(2): 751-754. View at Google Scholar | View at Publisher

Michael, A.T., A.M. McManus and R.S. Masters, 2005. Development and validation of a core endurance intervention program: Implications for performance in college-age rowers. Journal of Strength and Conditioning Research, 19(3): 547-552. View at Google Scholar $\mid$ View at Publisher

Odabaş, B., 2003. Effect of 12-week swimming basic education studies on physical and motorsal characteristics of boys and girls' boys 7-12. Kocaeli, Kocaeli University Institute of Health Sciences, Master Thesis.

Patil, D., S.C. Salian and S. Yardi, 2014. The effect of core strengthening on performance of young competitive swimmers. International Journal of Science and Research, 3(6): 2470-2477. View at Google Scholar

Ping, Q., W. Chaoying and Z. Weitao, 2011. Application of SEBT on core training measurement on fin swimming athletes. In Future Computer Science and Education (ICFCSE), 2011 International Conference on. IEEE. pp: 344-347.

Riewald, S.T., 2003. Training the other core. Performance Training Journal, 2(3): 5-6. View at Google Scholar

Rostami, R. and M. Ghaedi, 2017. Core stabilization training and fundamental motor skills in children. International Journal of School Health, 4.(1): e36010.

View at Google Scholar $\mid$ View at Publisher
Saeterbakken, A.H., R. Van den Tillaar and S. Seiler, 2011 . Effect of core stability training on throwing velocity in female handball players. Journal of Strength \& Conditioning Research, 25(3): 712-718. View at Google Scholar $\mid$ View at Publisher

Samson, K., 2005. The effects of a five-week core stabilization-training program on dynamic balance in tennis athletes. Tesis para optar al grado de Master of Science in Athletic Training]. USA: Universidad de West Virginia.

Samson, K.M., M.A. Sandrey and A. Hetrick, 2007. A core stabilization training program for tennis athletes. Athletic Therapy Today, 12(3): 41-46. View at

Google Scholar $\mid$ View at Publisher
Sarikaya, M., V. Cinar and M. Selcuk, 2016. Examination on the effect of the training program implemented during preparation period on the physical characteristics of tennis players. International Journal of Sport Studies, 6(10): 607-61 1. View at Google Scholar

Troup, J.P., 1999. The physiology and biomechanics of competitive swimming. Clinics in Sports Medicine, 18(2): 267-285 View at Google Scholar $\mid$ View at Publisher

Yapıcı, A., B. Maden and G. Findıkoğlu, 2016. The effect of 6 weeks of land and resistance training on the lower limb isokinetic strength performance and swimming rating of 13-16 age group swimmers, and the effect of a 6-week land and resistance training on 13-16 years old swimmers groups to lower limb isokinetic strength values and swimming performance. Journal of Human Sciences, 13(3): 5269-5281. View at Publisher

Yuksel, O., Y. Akkoyunlu, M.B. Karavelioğlu, H. Harmanc1, M. Kayhan and K.O.Ç. Harun, 2016. The effects of core strenght training on balance and shot percantage on male basketball players. Marmara University Sports Science Journal, 1(1): 49-60. 